\title{
Comparative epidemiological analysis on two-batch study of breast cancer in Dr. Cipto Mangunkusumo Hospital, Jakarta - Indonesia
}

Setyawati Budiningsih*, Yoshiyuki Ohno ${ }^{\dagger}$, Joedo Prihartono*, Drupadi S Dillon\#, Gunawan Tjahjadi§, Esti Soetrisno§, Endang Hardjolukito§, Didid Tjindarbumi, Muchlis Ramli , Idral Darwis`,Goi Sakamoto"l, Kenji Wakai ${ }^{\dagger}$, Santoso Cornain $\$$

\begin{abstract}
Abstrak
Untuk menganalisa berbagai faktor risiko pada kanker payudaya di antara wanita Indonesia, penelitian epidemiologik dilakukan dalam dua tahap, menggunakan cara studi kasus-kontrol yang baku. Tiga ratus kasus kanker payudara dibandingkan dengan 600 kelola yang matched selama studi tahap pertama pada tahun 1988-1991 dan 226 kasus dibandingkan dengan 252 kelola selama studi tahap kedua pada tahun 1992-1995. Data dianalisa dengan menghitung Odds Ratio untuk menetapkan kemaknaan berbagai faktor risiko, dan dilakukan baik analisa univariat maupun analisa multivariat. Hasilnya dievaluasi terhadap konsistensinya di antara kedua penelitian tersebut. Penelitian tahap pertama menunjukkan bahwa beberapa faktor risiko meningkatkann risiko secara bermakna, baik pada analisa univariat maupun multivariat, i.e. menarche yang terlambat, trauma payudara, menopause, masa laktasi yang pendek, konsumsi lemak yang tinggi; sedangkan konsumsi protein yang tinggi hanya meningkatkan risiko pada analisa univariat. Faktor-faktor tersebut tidak menunjukkan risiko bermakna pada penelitian tahap kedua.
\end{abstract}

\section{Abstract}

In order to analyze various risk factor in breast cancer among Indonesian women, epidemiologic studies were performed in two batches, using standard case-control study method. Three hundreds breast cancer cases were compared to 600 matched controls during the first batch study in 1988-1991 and 226 cases were compared to 252 controls during the second batch study in 1992-1995. The data were analyzed by calculating the Odds Ratios for determining the significance of various risk factors, and both univariate and multivariate analysis were performed. The findings were evaluated for their consistency between the two studies. The first batch study showed that several risk factors significantly increased the risk in both univariate and multivariate analysis, i.e. late menarche, breast trauma, menopause, short lactation, high fat consumption, while high protein intake increased the risk only in univariate analysis. They were not significantly shown in the second batch study.

Keywords: Epidemiological analysis, breast cancer, comparative study

\section{INTRODUCTION}

Many studies on epidemiological aspects of breast cancer have been performed, with special interest on various risk factors related to different ethnicity, specific lifestyles and reproductive status. ${ }^{1-3}$ Special interest has been given to the role of hormonal contraception. ${ }^{4-6}$ Several investigators also reported the protective effect of breast feeding. 7,8

So far, the findings might be varied, showing certain difference between different geographical areas and different ethnic groups. Therefore, such studies in a heterogeneous population like Indonesia will be interesting. During the last 15 years, Indonesia has been in transition from the agricultural to industrial country. There are many changes in life style, urbanization dietary pattern and nutritional status of the people. All these factors could affect the epidemiologic pattern of disease, including degenerative and neoplasm. The epidemiologic data already shows that non-infectious diseases are becoming more and more prevalent. In 1986 cancer rank as the ninth cause of death, while in

\footnotetext{
* Department of Community Medicine, Faculty of Medicine, University of Indonesia, Jakarta 10320, Indonesia

+ Department of Preventive Medicine. School of Medicine, Nagoya University, Nagoya 466, Japan

\# Department of Nutrition, Faculty of Medicine, University of Indonesia, Jakarta 10430, Indonesia

$\$$ Department of Pathology, Faculty of Medicine, University of Indonesia, Jakarta 10430, Indonesia

- Department of Surgery, Faculty of Medicine, University of Indonesia, Jakarta 10430, Indonesia

I Department of Pathology, Cancer Institute Hospital, Tokyo 170, Japan
} 
1992, it became number three. 1 The life expectancy also increase, for women in 1967 it is 47.2 years and in 1992 become 64.5 years, ${ }^{2}$ while the percentage of women are more than 45 years also increase.

Breast cancer (BC) in Indonesia was the second prevalent cancer among women, after cervical cancer. ${ }^{2}$ For Indonesia this situation should be anticipated with a different strategy, which should be based on epidemiological pattern of breast cancer. To date many small scale studies on BC has been conducted, but large studies were rare. Two large case-control studies have been conducted by the Medical School of University of Indonesia, in cooperation with School of Medicine Nagoya University and Tokyo Cancer Institute. The joint study was based in the same interest to identify risk factors on BC in Indonesia and to compare with the situation in Japan. These differences could be influence by geographical and cultural factors.

The first batch study collected 300 triplets during 1988-1991 and the second batch collected 226 triplets during 1992-1995. The first study objective was to identify risk factors on $\mathrm{BC}$ among Indonesian women, especially who came to Dr. Cipto Mangun- kusumo Hospital in Jakarta, which is the to referal hospital for the country. The second study objective was to know more about the role of fat dietary pattern on BC. This paper is aimed to look for consistency in $\mathrm{BC}$ risk factors between the two studies. Results of the studies will help the Health Ministry or other institution to support in developing strategy to prevent BC in Indonesia.

\section{METHODOLOGY}

The two studies were carried out as a hospital based study, conducted in Dr. Cipto Mangunkusumo Hospital in Jakarta. This hospital is the top referal hospital in Indonesia and Jakarta. The cases and controls were taken from the Surgery Department, which serve as the hospital base population. The two studies use the some methodology, where each case has 2 controls, matched for age and socio-economic levels. The cases had to be histopathology confirmed before included in the study, except for cases at stage IIIA above. This was approved, because many advanced cases did not come back for biopsy.11 Age are matched within \pm 3 years, while socio-economic level was defined as the level of hospital which the client plan to have if she has to stay in the hospital.

Table 1. Comparative demographics characteristics in batch 1 and 2 breast cancer study

\begin{tabular}{|c|c|c|c|c|c|c|c|c|}
\hline \multirow{3}{*}{ Characteristic } & \multirow{2}{*}{\multicolumn{4}{|c|}{ BATCH 1}} & & \multicolumn{3}{|c|}{ BATCH 2} \\
\hline & & & & & & & & \\
\hline & $\mathrm{n}$ & $\%$ & $\mathrm{n}$ & $\%$ & $\mathrm{n}$ & $\%$ & $\mathrm{n}$ & $\%$ \\
\hline \multicolumn{9}{|l|}{ AGE } \\
\hline$<30$ & 15 & 4.7 & 30 & 5.0 & 3 & 0.01 & 4 & 0.9 \\
\hline $30-39$ & 70 & 23.3 & 167 & 27.9 & 64 & 29.7 & 136 & 30.1 \\
\hline $40-49$ & 93 & 31.0 & 155 & 25.8 & 68 & 30.1 & 141 & 31.2 \\
\hline $50-59$ & 55 & 18.3 & 125 & 20.8 & 65 & 28.7 & 115 & 25.4 \\
\hline$\geq 60$ & 67 & 22.7 & 123 & 20.5 & 26 & 11.5 & 56 & 12.4 \\
\hline \multicolumn{9}{|l|}{ EDUCATION } \\
\hline Illiterate & 78 & 26.0 & 149 & 24.9 & 31 & 13.7 & 65 & 14.4 \\
\hline Elementary & 108 & 36.0 & 195 & 32.5 & 88 & 38.9 & 142 & 31.4 \\
\hline Junior high school & 46 & 15.3 & 93 & 15.5 & 34 & 15.0 & 98 & 21.7 \\
\hline Senior high school & 53 & 17.7 & 146 & 24.3 & 47 & 20.8 & 116 & 25.7 \\
\hline University & 15 & 5.0 & 17 & 2.8 & 26 & 11.5 & 31 & 6.9 \\
\hline \multicolumn{9}{|l|}{ STAGING } \\
\hline Stage I & 14 & 4.7 & 3 & 1.3 & & & & \\
\hline Stage II & 45 & 15.3 & 27 & 12.0 & & & & \\
\hline Stage IIIa & 68 & 22.7 & 40 & 17.7 & & & & \\
\hline Stage IIIb & 116 & 38.7 & 127 & 56.4 & & & & \\
\hline Stage IV & 56 & 18.6 & 29 & 12.0 & & & & \\
\hline \multicolumn{9}{|l|}{ MARITAL STATUS } \\
\hline Single & 23 & 7.7 & 39 & 6.5 & 2 & 0.9 & - & - \\
\hline Separate & 16 & 5.3 & 72 & 12.0 & 14 & 6.2 & 11 & 2.4 \\
\hline Widow & 64 & 21.3 & 157 & 26.2 & 31 & 13.7 & 86 & 19.0 \\
\hline Married & 197 & 65.7 & 39 & 55.0 & 177 & 78.3 & 354 & 78.3 \\
\hline \multicolumn{9}{|l|}{ LENGTH OF STAY } \\
\hline Urban area & 195 & 65.0 & 482 & 70.5 & 162 & 71.7 & 341 & 75.5 \\
\hline Rural area & 105 & 35.0 & 117 & 29.5 & 64 & 28.3 & 111 & 24.5 \\
\hline
\end{tabular}


Interviewers for the first study were nurse from the surgery department, added with public health nurse for the first three months. While in the second study, besides of the same nurse from the surgery department, nutritionist nurses were used because in the second study, a micro nutrient information were collected. In both studies, diagnose of cases were done by the surgeon. The difference in time period for collecting case and its control is 3 months.

To compare the two studies, statistical analysis was carried out using SPSS package. Odds ratios for univariate and multivariate were compared to access the risk ratio in each study and the consistency of the two findings.

\section{RESULTS}

Table 1 shows that age of the two studies were slightly different in distribution. The first study showed that the mean age of the cases was older than the second study $(\mathrm{X} 1=46.9$ yrs versus $\mathrm{X} 2=46.4$ yrs). Education for the studies are almost the same. For the staging of $\mathrm{BC}$, patient in the first study come at a more earlier stage (stage I: $4.7 \%$ versus $1.3 \%$ and stage II : $15.3 \%$ versus $12.0 \%$ ). Marriage status for cases and controls are higher in the second study, while the longest place of living give the same figures.

Table 2. Comparative odds ratio of selected risk factors on breast cancer

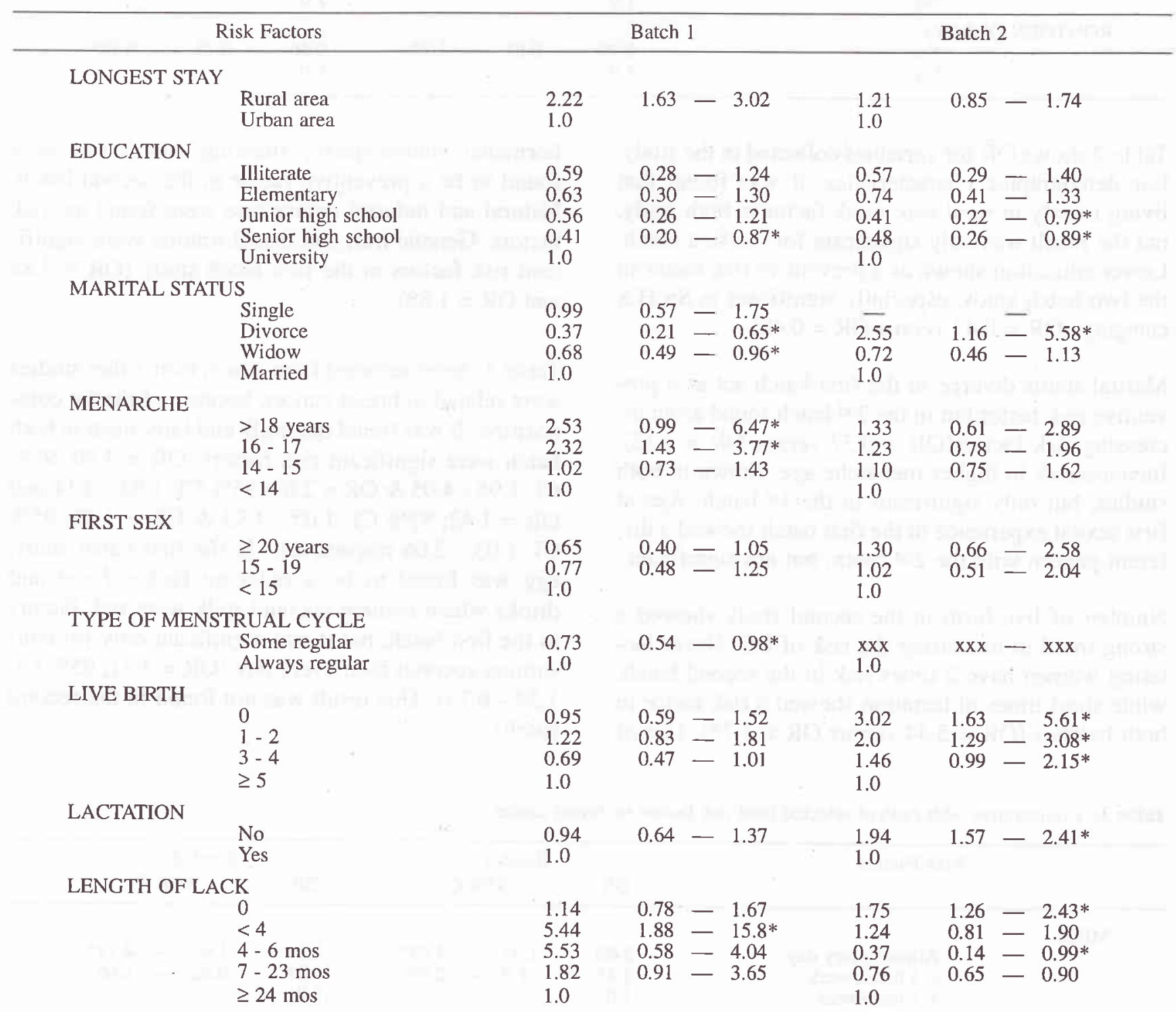




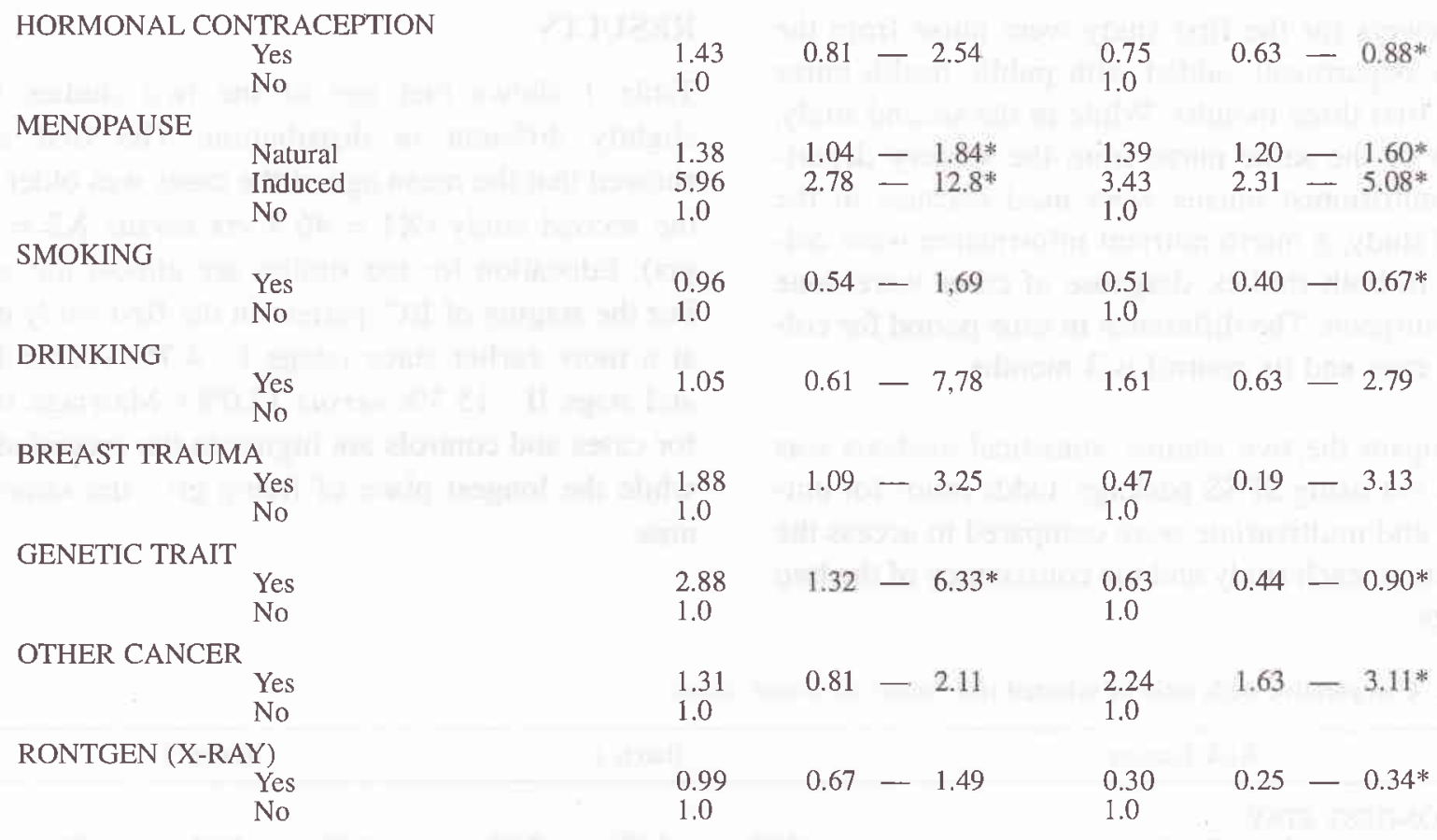

Table 2 shows OR for variables collected in the study. For demographic characteristics, it was found that living mostly in rural was a risk factor in both study, but the result was only significant for the first batch. Lower education shown as a preventive risk factor in the two batch study, especially significant in Sn H.S category $(\mathrm{OR}=0.41$ versus $\mathrm{OR}=0.48)$.

Marital status divorce in the first batch act as a preventive risk factor but in the $2^{\text {nd }}$ batch found as an increasing risk factor $(\mathrm{OR}=0.37$ versus $\mathrm{OR}=2.55)$. Increase risk in higher menarche age, shown in both studies, but only significant in the 1 st batch. Age at first sexual experience in the first batch showed a different pattern with the $2^{\text {nd }}$ batch, but not significant.

Number of live birth in the second study showed a strong trend in increasing the risk of BC. Never lactating women have 2 times risk in the second batch, while short times in lactation showed a risk factor in both batches $(\mathrm{OR}=5.44$ versus $\mathrm{OR}=1.75)$. Use of hormonal contraceptive, smoking and X-ray were found to be a preventive factor in the second batch. Natural and induced menopause were found as risk factors. Genetic trait and breast trauma were significant risk factors in the first batch study $(\mathrm{OR}=2.88$ and $\mathrm{OR}=1.88$ ).

Table 3 shows selected food which from other studies were related to breast cancer, because of the fat composition. It was found that milk and fatty meat in both batch were significant risk factors, $\mathrm{OR}=2.80 ; 95 \%$ CI: $1.95-4.05 \&$ OR $=2.83 ; 95 \%$ CI: $1.93-4.14$ and $\mathrm{OR}=1.42 ; 95 \%$ CI: $1.05-1.93 \& \mathrm{OR}=1.46 ; 95 \%$ CI: $1.03-2.06$ respectively. In the first batch study, egg was found to be a reducing factor. Food and drinks which contain coconut milk were risk factors in the first batch, but it was significant only for consuming coconut food every day $(\mathrm{OR}=3.21 ; 95 \% \mathrm{CI}$ : $1.54-6.73)$. This result was not found in the second batch.

Table 3. Comparative odds ratio of selected food risk factors on breast cancer

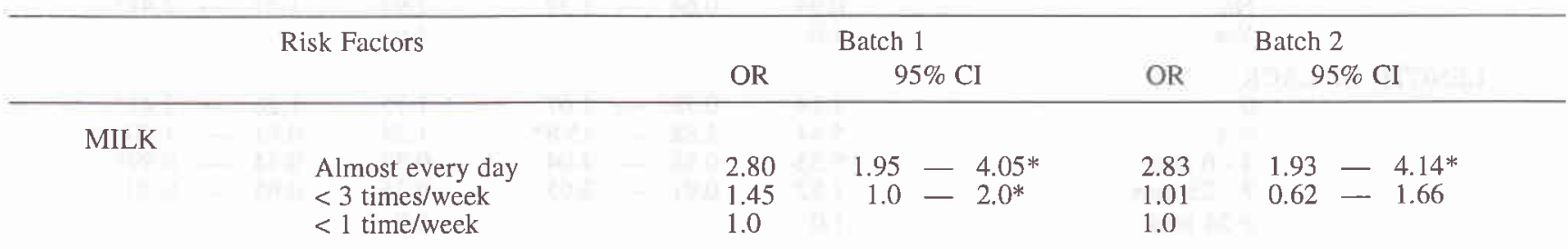


EGG

Almost every day
$<3$ times/week
$<1$ times/week

FATTY MEAT

Almost every day

$<3$ times/week

$<1$ times/week

COCONUT MILK DRINK

Almost every day

$<3$ times/week

$<$ l times/week

COCONUT FOOD

Almost every day

$<3$ times/week

$<1$ times/week
0.87

0.43

1.0

2.27
1.42

1.42
1.0

$0.64-8.06$

$1.05-1.93 *$

$0.54-1.41$

1.03

0.75

$0.66-1.60$

1.0

$0.50-1.12$

2.04

1.25

$0.0-74.79 *$
$0.74-2.12$

1.59

1.46

1.0

$0.69-3.60$

$1.03-2.06^{*}$

1.0

3.21

1.28

1.0

$$
\begin{aligned}
& 1.54-6.73 \text { * } \\
& 0.94-1.7
\end{aligned}
$$

\section{0}

0.66

$0.0-1.88$

1.0

\subsection{5}

0.84

1.0
$0.36-1.51$
$0.59-1.18$
Table 4 shows the OR of selected "reducing factors" for BC. In general, the food items which are considered a reduced risk factors shown to be risk factors in both batch studies. Diet of less than 3 times a week consuming juice, fresh fruit, green vegetable and non-fatty meat or fatty food or coconut milk drink al- most every day in the first batch, in the Table 5, showed to be a potential risk factor for breast cancer $(\mathrm{OR}=2.63 ; 95 \% \mathrm{CI}: 1.49$ - 4.79), while in the second batch, eventhough not significant, but showed the same trend.

Table 4. Comparative odds ratio of selected preventive risk factors on breast cancer

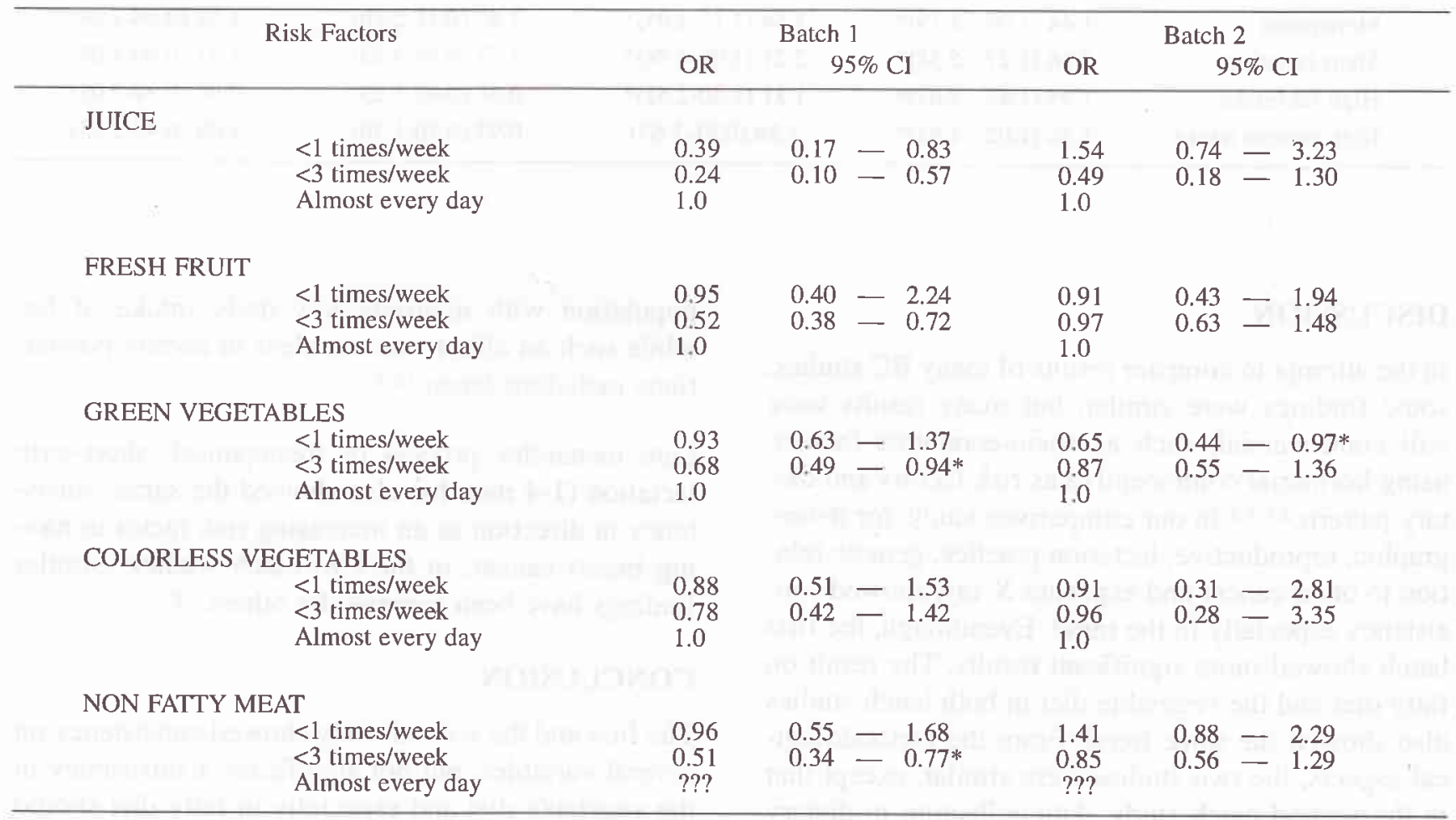


Table 5. Comparative odds ratio of vegetable and fatty diet

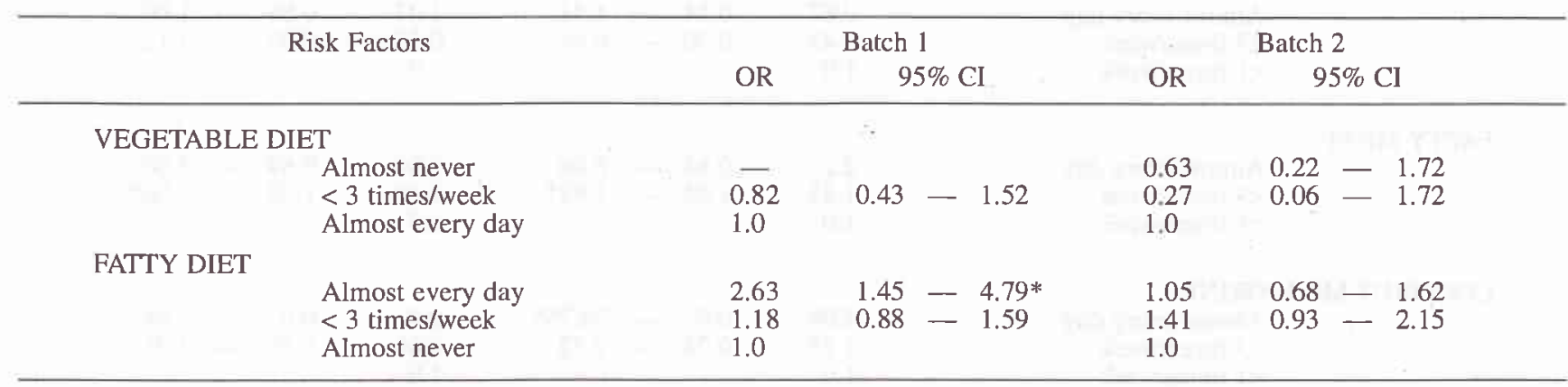

To gained more information on how these factors are related, a multivariate logistic regression result shown in Table 6. The result showed that in the first study, the 6 variables (menarche $<16$ years, breast trauma, natural menopause, lactation less than 6 months, intake fatty diet almost every day (excess fat) and intake egg and meat everyday (high protein), were risk factors in the univariate analysis. But after multivariate analysis 5 variables still gave the same result. The second batch study did not differ much at the univariate and multivariate analysis.

Table 6. Comparative odds ratio of univariate and multivariate of selected risk factors

\begin{tabular}{|c|c|c|c|c|}
\hline \multirow[t]{2}{*}{ Risk Factors } & \multicolumn{2}{|c|}{ Batch 1} & \multicolumn{2}{|c|}{ Batch 2} \\
\hline & Univariate & Multivariate & Univariate & Mutivariate \\
\hline Late menarche & $2.33(1.60-3.38)^{*}$ & $2.35(1.60-3.44)^{*}$ & $1.18(0.80-1.72)$ & $1.09(0.46-2.56)$ \\
\hline Breast trauma & $1.94(1.12-3.37)^{*}$ & $1.98(1.60-3.44) *$ & $0.44(0.17-1.22)$ & $0.45(0.12-1.80)$ \\
\hline Menopause & $1.44(1.09-1.19)^{*}$ & $1.54(1.15-2.05)^{*}$ & $1.52(0.11-2.10)$ & $1.52(0.68-3.39)$ \\
\hline Short lactation & $2.16(1.27-5.38) *$ & $2.21(1.02-4.78)^{*}$ & $1.57(0.35-2.53)$ & $1.57(0.60-4.08)$ \\
\hline High fat intake & $1.95(1.42-2.67)^{*}$ & $1.81(1.30-2.52)^{*}$ & $0.86(0.60-1.23)$ & $0.90(0.39-2.05)$ \\
\hline High protein intake & $1.36(1.02-1.81)^{*}$ & $1.24(0.91-1.67)$ & $0.97(0.70-1.36)$ & $1.09(0.49-2.43)$ \\
\hline
\end{tabular}

\section{DISCUSSION}

In the attempt to compare results of many $\mathrm{BC}$ studies, some findings were similar, but many results were still controversial, such as socio-economic factors, using hormonal contraceptive as risk factors and dietary pattern. 3,4,7,8 In our comparison study, for demographic, reproductive, lactation practice, genetic relation to other cancer and exposure X-ray, showed consistency especially in the trend. Eventhough, the first batch showed more significant results. The result on fatty diet and the vegetable diet in both batch studies also showed the same trend. From the methodological aspects, the two studies were similar, except that in the second batch study, data collecting in dietary pattern was more thoroughly. The present findings have been considered important increased risk of breast cancer due fat consumption was shown in the population with relativity low daily intake of fat, while such an affect was not clear in certain populations including Japan. ${ }^{12-15}$

Late menarche, process of menopausal, short-term lactation (1-4 months) also showed the same consistency in direction as an increasing risk factor in having breast cancer, in the two batch studies. Similar findings have been reported by others. 7,8

\section{CONCLUSION}

The first and the second study showed consistency on several variables, but not significant. Consistency in the vegetable diet and especially in fatty diet should be further studied in the future, because Indonesia consists of many ethnic groups which each has its own dietary pattern. 


\section{Acknowledgments}

The authors like to thank to the nurses, Ms. Ros and Emi, and public health nurses, Ms. July and Ms. Erlaini for excellent epidemiological data collection. We are also indebted to SDP staffs for helping in data processing.

This work was supported by the Ministry of Education, Science, Sports and Culture of Japanese Government, Grants No. 01042007, 04042013 and 06042006, and was partially supported by the Indonesian Cancer Foundation. This collaborative study was a part of Special Cancer Research project in Monbusho International Scientific Research Program, with the approval of the Dean, Faculty of Medicine, University of Indonesia, No. 4383/PT02.H4.FK/E/88.

\section{REFERENCES}

1. Donn AS, Muir CS. Breast cancer: Epidemiology and risk factors. In: Khogali M, Omar YT, Gjortov A, Ismail AS, Editors. Cancer prevention in developing countries. Oxford: Pergamon Press, 1986: 155-66.

2. Boyd NF. Epidemiology of Cancer, In Tannock IF, Hill RP, Editors the Basic Science of Oncology $2^{\text {nd }}$ ed N. York: Mc Graw Hill lnc, 1992: 7-22.

3. Hsieh CC, Trichopoulos D, Katsouyanni K, Yuasa S. Age at menarche, age at menopause, Height and weight and obesity as risk factors for breast cancer: Association and interactions in an International case-control study. In J Cancer 1990; 46: 796-800.

4. Lee NC, Rosero Bixby L, Oberle MW, Grimaldo C, Whatley AS, Rovira EZ. A case control study of breast cancer and hormonal contraception in Costa Rica. JNCI 1987; 79: 1247-54.

5. Stadel BV, Schlesseman JJ, Murray PA. Oral contraceptive and breast cancer. Lancet 1989; 1: 1257-8.

6. Stanford JL, Brinton HRN. Oral contraceptive and BC: Result from an expanded case-control study. $\mathrm{Br} \mathrm{J}$ Cancer, 1989; 60: $375-81$.

7. Mc Tiernan A, Thomas DB. Evidence for a protective effect on lactation on risk of breast cancer in young women. Result of a case-control study. Am J Epidemiol 1989; 124: 353-8.

8. Siskind V, Schofield F, Rice D, Bain C. Breast cancer and breast-feeding: Result from an Australian case-control study. Am J Epidemiol 1989; 130: 229-36.

9. Ministry of Health of Indonesia: Health profile in Indonesia, 1993.

10. Cornain S, Mangunkusumo R, Prihartono J, Nasar IM. Ten most frequent cancers in Indonesia: pathology based cancer registry data of 1988-1992. In Cancer registry in Indonesia. National Cancer Registry Center, Jakarta Coordinating board, 1992 .

11. Tjindarbumi D. Management and result of operable breast cancer in several hospitals in Jakarta: A 10- year survival rate observation. Indon J Oncol 1991; 2: 147-60.

12. Wakai K, Ohno Y, Watanabe S, Sakamoto G, Suzuki S, Kubo F. Risk Factors of breast cancer among Japanese women in Tokyo. A case control study. J Epidemiol 1994; 4: 65-71.

13. Ohno Y. Methodology and evaluation of dietary factors in Japan. In: Mettline CJ. Aoki K, editors. Recent progress on nutrition and cancer. N. York: Willey Liss Inc, 1990: 11-20.

14. Lee HP, Gourley L, Duffy SW, Esteve J, Day NE. Dietary effects in breast cancer in Singapore. Lancet 1991; 337: 1197200.

15. Kato I, Miura S, Kasumi F, Iwase T, Tashiro H, Fujita Y, et al. A case-control study of breast cancer among Japanese women, with special reference to family history and reproductive and dietary factors. Breast Cancer Res Treat 1992; 24: $51-9$. 